\title{
Normative and Institutional Foundations of Modern State Policy Regarding Complainers Abroad
}

\section{Elena Nikitina, Irina Tarbeeva, Elena Vasileva, and Tatiana Zerchaninova}

Russian Presidential Academy of National Economy and Public Administration, Yekaterinburg, Russian Federation

\section{Abstract}

Currently, about 30 million [8] compatriots live in the world who finds themselves outside of Russia. The collapse of the USSR and the formation new independent states saw millions of Russian people separated from Russia by borders, and faced discrimination on the basis of language, which caused an increase in the migration activity of the Russian population in the post-Soviet space. This situation requires a review of the principles and directions state authorities' activity in the migration sphere and determination of the necessary regulatory legal framework for regulating the processes of the influx of migrants from the former Soviet republics to Russia. The purposes of the research are 1) to study the regulatory and institutional foundations of modern public policy in relation to compatriots abroad and 2) to identify its main directions. The main research method is the analysis of official documents, regulatory legal acts, reporting and analytical documents of authorities implementing the state policy regarding compatriots living abroad. The state policy of the Russian Federation regarding expatriate citizens is a system of legal, diplomatic, social, economic, and organizational measures aimed at supporting and protecting Russian compatriots, ensuring the exercise of their rights and legitimate interests, as well as creating conditions under which they could would live as equal citizens in foreign countries or return to the Russian Federation. The state policy of the Russian Federation regarding compatriots abroad is implemented in two opposite directions, which significantly reduces its effectiveness. The mechanisms for implementing this policy are various forms of horizontal and vertical cooperation and interaction in various fields such as humanitarian, social, educational, cultural, and economic. A significant number of policy implementation entities required the creation and use of modern mechanisms for coordinating their activities. The resources spent on the return of compatriots to their homeland are not able to compensate for the emigration outflow from Russia, however, mechanisms aimed at solving the latter problem are not provided. In fact, the local population is excluded from the scope of this policy, which entails a number of problems associated not only with the attitude of the host society towards the migrants, but also with the desire of a significant part of the youth to leave Russia.

Keywords: state policy, compatriots, institutions. 


\section{Introduction}

The state policy in relation to compatriots abroad has the modern integral part of Russia's foreign policy which serves to ensure the national interests of the country.

In the most general form, the directions of interaction between the state and compatriots include: 1 ) protecting the rights and interests of Russian citizens and compatriots living abroad, considering the Russian World as a partner, including to expand the space of the Russian language; 2 ) assistance in the consolidation of compatriots, preservation of the ethnocultural identity of the Russian Diaspora and its connection with the historical homeland; 3 ) the implementation of the public diplomacy of the "Russian World" in the interests of developing cooperation with foreign countries, as well as managing the image of Russia in foreign countries [1].

As the Diaspora in the far abroad continues to grow, the authorities of the Russian Federation are developing a program for its involvement in the global "Russian World" [2]. The article discusses modern state policy in relation to compatriots abroad through an analysis of social institutions that regulate state and non-state support of compatriots abroad.

\section{Methodology and Methods}

The main research method is the analysis of official documents, regulatory legal acts, reports and analytical documents of authorities implementing the state policy regarding compatriots living abroad.

\section{Results and Discussion}

State policy of the Russian Federation with respect to compatriots abroad is a system of legal, diplomatic, social, economic, organizational measures aimed at supporting, protecting Russian compatriots, ensuring the exercise of their rights and legitimate interests, as well as creating conditions under which they could live as equal citizens in foreign countries or return to the Russian Federation.

The state policy in relation to compatriots living abroad, in accordance with the Foreign Policy Concept, approved by Decree of the President of the Russian Federation of November 30, 2016 No. 640, is assigned to the section of international humanitarian cooperation and the protection of human rights [3]. The main tasks of the Russian Federation in this area are to protect the legitimate interests and rights of compatriots 
living abroad, their diverse support in two opposite directions: on the one hand, contributing to the consolidation and preservation of the identity of the Russian diaspora abroad, preserving its ties with the historical Motherland, and the other is contributing to the process of voluntary resettlement of compatriots and members of their families for permanent residence in the Russian Federation.

The main normative legal act establishing the principles, goals and main directions of the state policy of the Russian Federation in relation to compatriots abroad and the basis for the activities of the Russian Federation state authorities and state authorities of the constituent entities of the Russian Federation to implement this policy is the Federal Law of May 24, 1999 No. 99 «On the state policy of the Russian Federation with respect to compatriots abroad» [8].

In accordance with paragraph 3 of Article 5 of Federal Law of May 24, 1999 No. 99, the goals of the state policy of the Russian Federation with respect to compatriots are to provide state support to compatriots, including providing legal protection for their interests, as well as the conditions under which they could be equitable citizens to live in foreign countries or return to the Russian Federation.

In accordance with generally recognized principles and norms of international law, international treaties of the Russian Federation, the legislation of the Russian Federation, and also taking into account the legislation of foreign states, the Russian Federation assists compatriots in the implementation and enforcement of human and civil rights and freedoms, including the rights to: 1) use Russian language and native languages of the peoples of the Russian Federation for the development of spiritual and intellectual potential; 2) establish and freely maintain relations between compatriots and relations with the Russian Federation, as well as receive information from the Russian Federation; 3) create national-cultural autonomies, public associations and religious organizations of compatriots, the media and participate in their activities; 4) participate in the work of non-governmental organizations at the national and international levels; 5) participate in the development of mutually beneficial relations between the states of residence and the Russian Federation; 6) make free choice of place of residence or exercise the right to return to the Russian Federation.

For compatriots who make a significant contribution to the support of the Russian Federation and the development of relations with the Russian Federation, moral encouragement measures are provided.

The Federal Law of May 24, 1999 No. 99 provides for the main areas of their targeted support in the following areas: fundamental human and civil rights and freedoms (Article 
15), economic and social (Article 16), culture, language, religion and education (Article 17), information (Article 18).

In accordance with Article 14 of Federal Law of May 24, 1999 No. 99, discrimination against citizens of the Russian Federation living abroad may be the basis for reviewing the policy of the Russian Federation with respect to a foreign state in which such discrimination takes place. Non-compliance by a foreign state with universally recognized principles and norms of international law in the field of fundamental human and civil rights and freedoms with respect to compatriots is the basis for the adoption by the state authorities of the Russian Federation of measures provided for by international law to protect the interests of compatriots.

It should be noted that the need to protect Russian compatriots abroad, arising in case of danger to their life, may be associated with extraordinary circumstances, which is regulated by Decree of the President of the Russian Federation of November 2, 1994 No. 2058 "On measures in case of emergencies for activities foreign institutions of the Russian Federation and Russian citizens living abroad" [4]

Work with compatriots abroad is included in the implementation plan for 2019-2021 "Strategies of the state national policy of the Russian Federation for the period until 2025" [5]. Section X "Using the opportunities and mechanisms of international cooperation in the implementation of the state national policy of the Russian Federation" focuses on promoting the formation of a positive image of Russia abroad, consolidating the activities of associations of compatriots living abroad, ensuring their rights in countries of residence, and maintaining ties with historical homeland.

Interaction with compatriots is one of the areas of the state program "Foreign Policy Activities" [6]. Also, the Comprehensive Plan of the Main Activities for the Implementation of the State Policy of the Russian Federation for Compatriots Living Abroad, for 2018-2020, approved by the Government Commission on the Affairs of Compatriots Abroad on April 16, 2018 is in force [7]. In accordance with the Comprehensive Plan, the main tasks of interaction with compatriots living abroad include: a) ensuring the protection of the rights and legitimate interests of compatriots on the basis of international law and international treaties of the Russian Federation; b) facilitating the further consolidation of the Russian diaspora by supporting compatriots 'organizations at the global, regional and country levels, encouraging contacts of compatriots' organizations with Russian state and public structures, including religious associations; c) expanding the information support of compatriots and assisting in the formation of the media and Internet resources published by them; d) assistance in preserving the Russian linguistic and ethnocultural identity of compatriots; e) support for youth organizations of 
compatriots, Russian-speaking youth, preservation and development of their ties with the Russian Federation; f) support for socially vulnerable layers of compatriots.

In accordance with Article 21 of the Federal Law of May 24, 1999 No. 99 state administration and control in the field of relations with compatriots are carried out: 1) Federal level - by the Government of the Russian Federation and a specially authorized federal executive body; 2) Constituent entities of the Russian Federation - by executive authorities of the constituent entities of the Russian Federation.

The federal executive body of state power, carrying out the development and implementation of state policy in the field of international relations of the Russian Federation, is the Ministry of Foreign Affairs of the Russian Federation (MFA of Russia). Based on the Regulation approved by Decree of the President of the Russian Federation dated July 11, 2004 No. 865 "Issues of the Ministry of Foreign Affairs of the Russian Federation", facilitating the development of relations and contacts with compatriots abroad is defined as one of the tasks of the Russian Ministry of Foreign Affairs to implement the foreign policy of the Russian Federation, which it It carries out, inter alia, through coordination and control of the activities of the Federal Agency for CIS Affairs subordinate to it, compatriots living abroad, and international humanitarian cooperation to the country (Rossotrudnichestvo), including the development of a network of Russian centers of science and culture abroad.

The structural unit of the Ministry of Foreign Affairs of Russia, which is responsible for the formation of state policy with regard to compatriots abroad, is the department for working with compatriots abroad of the Ministry of Foreign Affairs of Russia (DRS). The structure of the DRS includes departments specializing in the most pressing problems. Among them is the analytical department, which forms the basis of the secretariat of the Government Commission on Compatriots Abroad (PCDSR), the coordinating body of the Government of the Russian Federation, which ensures coordinated actions by interested executive bodies to implement the state policy of the Russian Federation on this issue. The composition of the PCDSR includes representatives of the legislative and executive state authorities of the Russian Federation and its constituent entities. PKDSR carries out its activities in constant contact with public, religious and other organizations. The tasks of the commission are to summarize work experience, prepare recommendations and develop proposals for improving the regulatory framework.

In order to provide Russian compatriots with comprehensive legal and other necessary support in cases of violation of their rights, freedoms and legitimate interests, in accordance with generally recognized principles and norms of international human rights law, the non-profit organization "678" was established by the President of the 
Russian Federation on May 25, 2011 Fund to support and protect the rights of compatriots living abroad. "The founders of the Fund are the Ministry of Foreign Affairs of Russia and Rossotrudnichestvo. Targeted legal assistance to human rights organizations and individuals is provided through the allocation of grants and subsidies.

The supreme representative body ensuring the interaction of compatriots with government bodies of the Russian Federation and government bodies of the constituent entities of the Russian Federation is the World Congress of Compatriots, which is held at least once every 3 years. In the period between world congresses of compatriots, world conferences of compatriots are held. The delegates of the World Congress of Compatriots and World Conferences of Compatriots are elected by public associations of compatriots at conferences of compatriots in the countries of their residence.

In the period between the world congresses of compatriots and the world conferences of compatriots, the representation of interests of foreign compatriots in Russia is ensured by the World Coordinating Council of Russian Compatriots (VKS). Members of the videoconferencing participate in its work on a voluntary basis and at no cost. The Council has the status of a public association without a legal entity.

The basis of the organizational activities of the Russian foreign countries is regional and country coordination councils, which are formed from the most active representatives of the Russian diasporas abroad. Currently, there is a regional coordinating council of compatriots in Europe, a regional coordinating council of compatriots in the Asia-Pacific region, a regional coordinating council of compatriots in America, a regional coordinating council of compatriots in Africa and the Middle East, a regional coordinating council of compatriots in Northern Europe and the Baltic states.

Country Coordinating Councils of Compatriots (KSORS) are created in almost all countries where there are Russian diasporas. They are created to coordinate the activities of public associations and are elected from among their leaders. KSORS is an umbrella structure, under the auspices of which compatriots in the countries of residence for the purposes of their organizational and spiritual unity, as well as joint actions to protect the legitimate rights and interests of their members, preserve and popularize the Russian language and domestic culture, and strengthen ties with their historical homeland on a voluntary basis various public associations unite, including Russian-language media created by compatriots on the principles of self-sufficiency, Russian kindergartens, Russian schools, and hobby cooperation of compatriots [2, 11].

It should be noted that in modern conditions assistance in resolving issues of supporting compatriots abroad is implemented both at the federal level and at the regional level in the subjects of Russia. The intensification of joint efforts in this direction serves 
to increase the effectiveness of common work, which allows satisfying the diverse interests of the multimillion-dollar Russian diaspora abroad, and also helps to relocate some compatriots to the country.

The following main areas of work with compatriots living abroad have developed in the constituent entities of the Russian Federation: 1) participation of compatriots in international exhibition and sports events organized by the region as volunteers and translators; 2) the selection of partners and the provision of organizational support in the exchange of specialists in programs for studying the experience of foreign colleagues; 3 ) the use of Rossotrudnichestvo platforms and Russian Culture Centers for presentations of the region; 4) the development of partnerships between educational institutions of the region and schools abroad, providing instruction in Russian; 5) international youth exchanges; 6) implementation of civil-patriotic projects; 7) holding events for youth and participation of compatriots in youth projects in the region; 8) the development and implementation of state programs to facilitate the voluntary resettlement of compatriots.

\section{Conclusions}

The study has fixed that policy of supporting compatriots plays an important role in Russian foreign policy, especially at the regional level of the near abroad. Cooperation with compatriots is not a one-time gain; it is based on the desire to strengthen its position in the world with the help of the so-called "soft power", which can influence the formation of a positive image of the country as a whole and its subjects.

The state policy of the Russian Federation regarding compatriots abroad is implemented in two opposite directions [10], which significantly reduces its effectiveness. The mechanisms for implementing this policy are various forms of horizontal and vertical cooperation and interaction in various fields: humanitarian, social, educational, cultural, and economic.

\section{Funding}

The reported study was funded by RFBR, project number 20-011-00760.

\section{References}

[1] Chepinitskaya, P. R. (2012). State interaction with Russian compatriots abroad: the problem of reflective management. Vestnik MGIMO, vol. 2, issue 23, pp. 191-195. 
[2] Grunt, E. V. (2016, August). Russian speaking diaspora in contemporary France. Presented at Sgem 2016, Psychology and Psychiatry, Sociology and Healthcare, Education Conference International Multidisciplinary Scientific Conferences on Social Sciences and Arts Proceedings, Vol 2. Albena, Bulgaria, Stef92 Technology, pp. 835-842.

[3] Decree of the President of the Russian Federation of 30.11.2016 No. 640 "On approval of the Foreign Policy Concept of the Russian Federation". Retrieved February 20, 2020 from www.kremlin.ru/acts/bank/41451.

[4] Decree of the President of the Russian Federation of 02.11.1994 No. 2058 "On Measures in the Event of Emergencies for the Activities of Foreign Offices of the Russian Federation and Russian Citizens Abroad". Retrieved February 20, 2020 from base.garant.ru/103234/.

[5] Decree of the Government of the Russian Federation of 28.12.2018 No. 2985-r "On the plan of measures for implementation in $2019-2021$ Strategies of the state national policy of the Russian Federation for the period until 2025". Retrieved February 20, 2020 from yandex.ru/turbo?text=https\{\%]3A\{\%\}2F[\%\}2Ffzakon. ru\{\%\}2Frasporyazheniya-pravitelstva\{\%\}2Frasporyazhenie-pravitelstva-rf-ot-28.

12.2018-n-2985-r\{\%\}2F.

[6] Decree of the Government of the Russian Federation of 15.04.2014 N 325-10 "On approval of the state program of the Russian Federation Foreign Policy Activity". Retrieved February 20, 2020 from https://base.garant.ru/70644254/.

[7] Decision of the Government Commission on the Affairs of Compatriots Abroad of 16.04.2018 "A Comprehensive Plan of the Main Activities for the Implementation of the State Policy of the Russian Federation Regarding Compatriots Living Abroad for 2018-2020". Retrieved February 20, 2020 from rcnk.gr/images/2018/August/\%D0\% 9A\%D0\%BE\%D0\%BC\%D0\%BF\%D0\%BB\%D0\%B5\%D0\%BA\%D1\%81\%D0\%BD\%D1\% 8B\%D0\%B9_\%D0\%BF\%D0\%BB\%D0\%B0\%D0\%BD_2018-2020.docx.

[8] Federal Law of 05.24.1999 No. 99-FZ "On the State Policy of the Russian Federation Regarding Compatriots Abroad". Retrieved February 20, 2020 from www.consultant. ru/document/cons_doc_LAW_23178/.

[9] Mkrtchan, N. (2013). Russian Policy Towards Compatriots. In Migration in Russia 2000-2013. / Editor I. Ivanov. Moscow: Spetskniga, pp. 618-619.

[10] Molodikova, I. N. (2017). Russia's Policy in Respect of Compatriots Abroad: The Role of State and Public Institutions. Social Policy and Sociology, vol. 16, issue 1(120), pp. 123-132. 
[11] Mukomel, V. (2005). Migration Policy of Russia: Post-Soviet Contexts. Moscow: DipolT, p. 351. 